\title{
Two new species in the Drosophila flavopilosa and Drosophila morelia species groups (Diptera: Drosophilidae) in the eastern Andes of Ecuador
}

\section{Dos nuevas especies de los grupos Drosophila flavopilosa y Drosophila morelia (Diptera: Drosophilidae) en los Andes Orientales del Ecuador}

\author{
Emily Ramos Guillín* and Violeta Rafael
}

Laboratorio de Genética Evolutiva, Escuela de Ciencias Biológicas, Pontificia Universidad Católica del Ecuador, Apartado: 17-01-2184, Quito, Ecuador. ${ }^{*}$ Corresponding author

Email Emily Ramos Guillín: em.lis.ramos@hotmail.com

Email Violeta Rafael: vrafael@puce.edu.ec

\begin{abstract}
One species in the Drosophila flavopilosa species group and another in the Drosophila morelia species group (Diptera: Drosophilidae) are described and illustrated. The larvae of the flies in these groups develop exclusively in flowers and, usually, are rarely collected from rotten plant parts. However, in this case, these new species were not collected from flowers but were captured with fermented banana and yeast. It indicates that this species may be attracted to the odors of yeast fermentation and not only solanaceous flowers. The specimens were collected at $3362 \mathrm{~m}$ above sea level. There are four species of the Drosophila flavopilosa species group and one species of the Drosophila morelia species group previously described from Ecuador. The new species are: Drosophila pseudokorefae sp. nov. in the Drosophila flavopilosa species group and Drosophila pseudomorelia sp. nov. in the Drosophila morelia species group.
\end{abstract}

Keywords: Cloud forest; biodiversity; Napo province; Papallacta Lake; new species.

\section{Resumen}

Se describen e ilustran una especie del grupo Drosophila flavopilosa y otra del grupo Drosophila Morelia (Diptera: Drosophilidae). Las larvas de las moscas de estos grupos se desarrollan exclusivamente en flores y raramente se recolectan de partes de plantas en putrefacción. Sin embargo, en este caso, estas nuevas especies no se recolectaron de flores, sino que se capturaron con trozos de plátano fermentado y levadura. Lo cual, indica que esta especie puede ser atraída por los olores de la fermentación de levadura y no solo por las flores de solanáceas. Los especímenes fueron recolectados a $3362 \mathrm{~m}$ sobre el nivel del mar. Existen cuatro especies del grupo Drosophila flavopilosa y una especie del grupo Drosophila morelia previamente descrita en Ecuador. Las nuevas especies son: Drosophila pseudokorefae sp. nov. en el grupo Drosophila flavopilosa y Drosophila pseudomorelia sp. nov. en el grupo Drosophila morelia.

Palabras clave: bosque nuboso; biodiversidad; Provincia de Napo; Lago Papallacta; nuevas especies.

\section{Publicación registrada en Zoobank/ZooBank article registered:}

LSID urn:Isid:zoobank.org:pub:6200B0C8-4D03-4B7A-BDD3-E4A78077C1FE

Acto nomenclatural/nomenclatural act:

1. Drosophila pseudokorefae Ramos-Guillín \& Rafael, 2018

LSID urn:Isid:zoobank.org:act:3BD87C01-D29C-4371-993D-E1E196404A4E

2. Drosophila pseudomorelia Ramos-Guillín \& Rafael, 2018

LSID urn:Isid:zoobank.org:act:50C95E02-E089-4225-AEF8-80D6CC9738C6

Citation:

Ramos Guillín E. and V. Rafael. 2018. Two new species in the Drosophila flavopilosa and Drosophila morelia species groups (Diptera: Drosophilidae) in the eastern Andes of Ecuador. Revista peruana de biología 25(2): 069 - 074 (Mayo 2018). doi: http://dx.doi.org/10.15381/rpb.v25i2.14684

$\begin{array}{ll}\text { Presentado: } & 16 / 02 / 2018 \\ \text { Aceptado: } & 03 / 04 / 2018\end{array}$

Aceptado:

Publicado online: $30 / 05 / 2018$
Scientific Collecting Permits: Ministry of Environment granted collection permits No. 001-10 IC-FAU-DNB / MA and No. 001-11 IC-FAU-DNB / MA.

Funding: The Pontifical Catholic University of Ecuador financed the projects $\mathrm{N}^{\circ} \mathrm{J} 13054$ and $\mathrm{N}^{\circ} \mathrm{K} 13051$

Author Contributions: ERG, VR: conducted experimental design ERG, VR: performed the experiments; ERG, VR: drafted the manuscript reviewed and approved the manuscript.

The authors do not incur conflicts of interest. 


\section{Introduction}

Certain Neotropical drosophilid flies oviposit and complete larval development in living flowers and are rarely collected by net sweeping over decomposing plant material or fungi (Pipkin et al. 1966). Flies in the species groups D. bromeliae Sturtevant (1921); D. flavopilosa Frey (1919); D. onychophora Vilela \& Bächli (1990) and D. morelia Vilela (2004) develop exclusively in flowers (Figuero et al. 2011).

Robe et al. (2013) listed 17 species in their last revision of the $D$. flavopilosa species group. However, they did not include D. gilva which it was included in this group by Wheeler et al., (1962). Robe et al. (2013) also lists D. ogradi Vela \& Rafael (2004) as part of the D. flavopilosa species group but Santos and Vilela (2005) considered this species as part of the Drosophila morelia species group and Figuero et al. (2012) confirmed that $D$. ogradi is a member of the $D$. morelia species group.

Four species of the D. flavopilosa species group are present in Ecuador, D. korefae Vela \& Rafael (2004), D. sisa Vela \& Rafael (2005), D. suni Vela \& Rafael (2005) and D. taxohuaycu Vela \& Rafael (2005). With few exceptions the species of this group are entirely or mostly dull yellow in color; they have a rather high costal index, a single strong oral bristle and six acrostichal rows on the thorax. The male genitalia have a characteristic structure: the lower portion of genital arch generally has two long bristles; the "toe" is strongly bent forward, usually narrow and elongated and does not cover the clasper. The anal plate is oblong and fused with the genital arch. The penis is slender and long, curved ventrally and with a pair of apical lobes (Wheeler et al. 1962).

The Drosophila morelia species group has 4 species, D. carioca Vilela \& Bächli (2004) distributed in Brazil (State of Rio de Janeiro), D. fluminensis Vilela \& Bächli (2004) in Brazil (State of Rio de Janeiro), D. morelia Vilela \& Bächli (2004) in Mexico (State of Michoacán) and Panama (Province of Chiriquí) and D. ogradi Vela \& Rafael (2004). A clear-cut distinction based on external morphology is difficult because several character states overlap and there is considerable individual variability. However, in general these flies are yellowish with a narrow, nose-like carina. The tergites are not sulcate with a dark marginal band, which is triangular, medially broadened, almost reaching the anterior tergite, but usually very narrowly interrupted along the midline (Vilela \& Bächli 2004). The wings usually have a characteristic shadow across the distal half of the wing, leaving pale areas between the tips of the veins at the wing margin. The $\mathrm{hb}$ index is low, 0.29 . The surstylus and gonopod are partially microtrichose. The aedeagus is long, arch-shaped, parallel to the ventral rod and becoming narrow near the dorsodistal margin. The aedeagal apodeme is wider than longer and the ventral rod is long (Vilela \& Bächli 2004).

\section{Materials and methods}

The specimens were collected in Napo province in the northeast of Ecuador in the foothills of the Andes descending to the Amazon region. Collections were made at 3,362 m $\left(0^{\circ} 22^{\prime} 52.6^{\prime \prime} \mathrm{S}, 078^{\circ} 09^{\prime} 44.4^{\prime \prime W}\right)$. A transect of traps (40) was placed in each of three plots separated by five meters and one meter high from the base of the tree that marked the sampling locations. The traps were made from $500 \mathrm{ml}$ plastic bottles and baited with banana pieces $(2 \mathrm{~cm})$ previously fermented (one day before) with yeast.
Living flies in the traps were captured with an entomological aspirator and placed in a tube with standard Drosophila culture media. Dead flies were collected in microcentrifuge tubes with ethanol (70\%). The external morphology of each fly was examined under a stereomicroscope (Zeiss; Discovery V8) and measured with the AxioVision program. Terminalia were dissected out of the abdomen and placed in $\mathrm{KOH}(10 \%)$ and boiled for ten minutes. They were then placed in glycerol (60\%) for description, photography and preservation; before doublemounting in microvials and as dried mounted specimens. Indices of the paratypes are represented in parentheses. Descriptive terms and indices follow the system of Bächli et al. (2004).

Types and paratypes of the new species have been deposited in the Museo de Zoología - Invertebrados, Pontificia Universidad Católica del Ecuador, Quito (QCAZ).

\section{Results}

\section{Drosophila flavopilosa species group}

\section{Drosophila pseudokorefae sp. nov.}

(Figs. 1-6)

Type material. Male holotype (dissected, terminalia in microvial), labelled “D. pseudokorefae Holotype $\widehat{~}$, E. L. Ramos \& V. Rafael det. 2014 Ecuador, Napo, Papallacta (opposite from the west side of Papallacta Lake, across the road), 0 22'52.6”'S, 7809'44.4”W, 3,362 m). II. 08 Sep 2012, E.L. Ramos col., (QCAZI 3016)”. Paratype: $1 \delta^{\lambda}$ (dissected, terminalia in microvial), the same data as holotype (QCAZI 3017).

Diagnosis. Abdomen yellow without dorsal midline; tergite 1 without pigmentation; tergites $2-5$ with slight pigmentation in the distal part of each one. Hypandrium membranous, Vshaped and the posterior side with two horn-shaped projections. Epandrium microtrichose with four upper setae and 39 and 28 lower setae, right and left respectively. Aedeagus sclerotized long, curved, C-shaped noticeably bifid forming two serrated lobules with finger-shaped membranous projections. Wings light brown, hyaline posterior crossveins slightly infuscate.

Description. Head. Frons yellowish brown frontal length $0.5(0.4) \mathrm{mm}$; frontal index $=1.0(0.97)$, top to bottom width ratio $=1.4(1.4)$. Frontal triangle brown. Ocellar triangle yellowish brown, about 38\% (36\%) of frontal length, ocellus yellow. Orbital plate brown, the medial vertical setae is closer to lateral vertical setae and slightly toward the outer edge of the orbital plate, distance of or3 to or 1, 64\% (64\%) of or3 to vtm (orbitoindex, McEvey 1990), or 1/or3 ratio 0.8 (0.8), or2/or 1 ratio 0.8 (0.8), postocellar setae 29\% (31\%) and ocellar setae $81 \%(87 \%)$ of frontal length; vt index $=0.9(0.9)$, vibrissal index $=0.6(0.7)$. Frontal vitta yellowish brown. Gena and postgena yellow. Carina brown and sulcate. Oral setae prominent, the second slightly smaller than the previous one. Cheek index $=10.9$ (9.9). Eyes red wine in colour; eye index $=1.4(1.1)$.

First flagellomere brown. Aristae plumose, with 4 dorsal and 2 ventral branches, plus terminal fork. Proboscis yellow.

Thorax. Yellowish brown; length $1.2(0.8) \mathrm{mm}$ with thin dark lines that arise before the dorsocentral bristles with 6 rows of acrostichal setulae between the two anterior dorsocentral setae, 

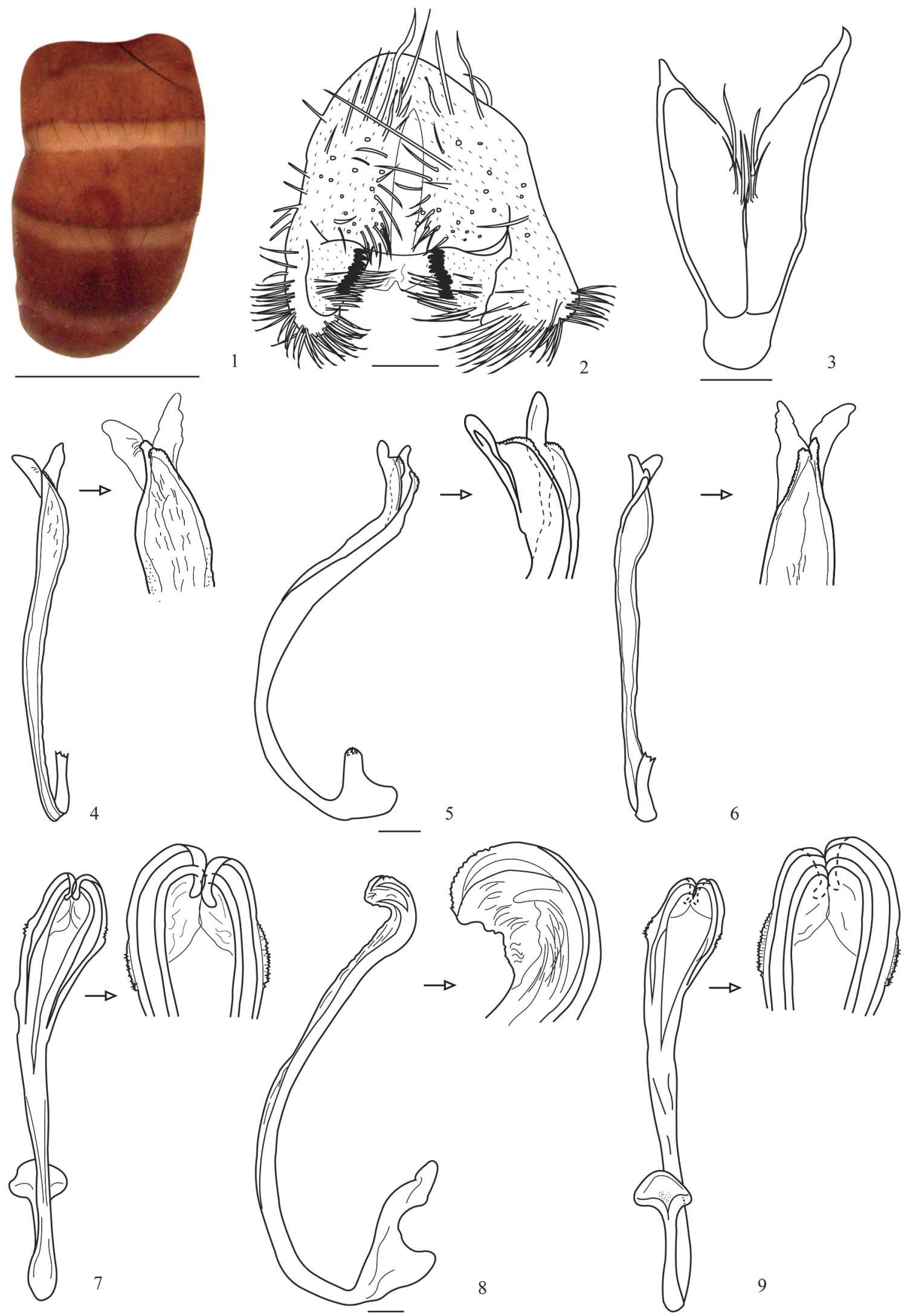

Figures 1 - 9. Drosophila pseudokorefae sp. nov. 1, abdomen (scale bar = 1mm); 2, epandrium, cerci, surstyli and decasternum; 3 , hypandrium and gonopods in ventral view; $4-6$, aedeagus in dorsal, lateral and ventral view, respectively; $7-9$, aedeagus of $D$. korefae in dorsal, lateral and ventral view, respectively zoom 40x (scale bar $=100 \mu \mathrm{m}$ ). 
$\mathrm{h}$ index $=1.3$ (1.2). Transverse distance of dorsocentral setae 1.9 (2.1) of longitudinal distance, $\mathrm{dc}$ index $=0.7(0.5)$. Scutellum yellow. Distance between apical scutellar setae $86 \%$ (83\%) of that between apical and basal setae; basal scutellar setae divergent; scut index $=1.2$ (1.1). Sterno index $=1.3$ (0.8). Legs yellow.

Wings light brown hyaline, posterior crossvein slightly infuscate, length $4.6 \mathrm{~mm}$ (3.9), length to width ratio $=2.5(2.4)$.

Indices: C, 4.7 (4.7); ac, 2.1 (1.9); hb, 0.2 (0.3); 4C, 0.5 (0.4); 4v, $1.3(1.3)$; 5x, $1.2(1.4)$; M, $0.3(0.4)$; prox. x, $0.4(0.4)$.

Abdomen (Fig. 1). Yellow without dorsal midline; tergite 1 without pigmentation; tergite 2-5 with slight pigmentation in the lower part of each one.

Male terminalia (Figs. 2 - 3). Epandrium (Fig. 2) microtrichose with four upper setae and 39 and 28 lower setae, right and left respectively. Cerci linked to epandrium. Surstylus rectangular and microtrichose with a row of 10 prensisetae in the right and 11 in the left, 16 inner setae in the right and 14 in the left. Hypandrium (Fig. 3) membranous, V-shaped and the posterior side with two horn-shaped projections. Gonopod oval with three long setae in the inner part.

Aedeagus (Figs. 4 - 6). Sclerotized long, curved, C-shaped, noticeably bifid forming two serrated lobules with finger-shaped membranous projections. Aedeagal apodeme (broken) membranous and rectangular.

Etymology. The word "pseudo" means false, or unreal. $D$. pseudokorefae was named because it resembles D. korefae.

Relationship to other species. Drosophila pseudokorefae belongs to the flavopilosa species group in the subgenus Drosophila. The general shape of the male terminalia, especially the aedeagus, suggests a close relationship to D. korefae.

\section{Drosophila morelia species group}

\section{Drosophila pseudomorelia sp. nov.}

$$
\text { (Fig. } 10-15)
$$

Type material. Male holotype (dissected, terminalia in microvial), labelled "D. pseudomorelia Holotype đิ , E. L. Ramos \& V. Rafael det. 2014 Ecuador, Napo, Papallacta (opposite from the west side of Papallacta Lake, across the road), 0'22'52.6"S, 7809'44.4"W, 3,362 m). II. 11 Nov 2012, E.L. Ramos col., (QCAZI 3014)". Paratype: $1 \delta^{\Uparrow}$ (dissected, terminalia in microvial), the same data as holotype (QCAZI 3015).

Diagnosis. Abdomen with dorsal midline; tergite 1 with a faint brown line; tergite 2-3 with dark brown lateral bands which increase in width apical slightly narrowed laterally. Epandrium microtrichose with 34 and 30 setae right and left respectively. Aedeagus poorly sclerotized, long, curved, C-shaped. Distal half twice as wide as anterior half, as seen in lateral view; bearing a dorsodistal, thin, process curved anteriorly, ending in a double tip.

Description. Head. Frons yellowish brown frontal length $0.3(0.4) \mathrm{mm}$; frontal index $=0.7(1.0)$, top to bottom width ratio $=1.4(1.4)$. Frontal triangle yellowish brown. Ocellar triangle dark brown, about $44 \%$ (46\%) of frontal length, ocellus yellow. Orbital plate dark brown, the medial vertical setae is closer to lateral vertical setae and slightly toward the outer edge of the orbital plate, distance of or3 to or $1,82 \%$ (99\%) of or3 to vtm (orbito-index, McEvey 1990), or1/or3 ratio 0.9 (paratype with or3 broken), or2/or1 ratio 0.5 (0.6), postocellar setae $62 \%(37 \%)$ and ocellar setae $88 \%$ (88\%) of frontal length; vt index $=1.1(0.9)$. Frontal vitta yellowish brown. Gena and postgena yellowish brown. Carina brown and sulcate. Oral setae prominent. Cheek index $=9.3$ (5.6). Eyes red wine in colour; eye index $=1.6(1.3)$.

First flagellomere yellowish brown. Aristae plumose, with 4 dorsal and 2 ventral branches, plus terminal fork. Proboscis yellow.

Thorax. Brown; length 1.5 (1.0) mm with 7 rows of acrostichal setulae between the two anterior dorsocentral setae, $h$ index $=1.5(1.5)$. Transverse distance of dorsocentral setae 1.9 (1.7) of longitudinal distance, $\mathrm{dc}$ index $=0.8(0.5)$. Scutellum yellowish brown. Distance between apical scutellar setae $90 \%$ (92\%) of that between apical and basal setae; basal scutellar setae divergent; scut index $=0.8(1.4)$. Sterno index $=0.6(0.9)$. Legs yellow.

Wings light brown hyaline, length $2.0 \mathrm{~mm}$ (1.9), length to width ratio $=2.4(2.4)$.

Indices: C, 4.5 (4.7); ac, 1.8 (1.8); hb, 0.1 (0.2); 4C, 0.5 (0.4); 4v, 1.1 (1.1); 5x, 1.4 (1.4); M, 0.3 (0.3); prox. x, $0.3(0.3)$.

Abdomen (Fig. 10). Beige with dorsal midline; tergite 1 with a faint brown line; tergite 2-3 with dark brown lateral bands which increase in width apically, slightly narrowed laterally.

Male terminalia (Fig. 11 - 12). Epandrium (Fig. 11) microtrichose with 34 on the right and 30 on the left seta. Cerci linked to epandrium. Surstylus rectangular with a row of 10 prensisetae on the both sides and 13 inner setae on the right and 15 inner setae on the left. Hypandrium (Fig. 12) poorly sclerotized $\mathrm{V}$-shaped and with two horn-shaped projections on the posterior side. Gonopod rectangular with two setae on the left and on the proximal (left) part and with one seta and a hole on the distal (right) part.

Aedeagus (Figs. 13-15) poorly sclerotized long, curved, Cshaped. The last part (lp) is twice as wide as the proximal part, as seen in lateral view; bearing a dorsodistal process, thin and curved anterior, terminating in a double tip; subdistal margins of ventral area serrated. Aedeagal apodeme reduced; paraphysis oval.

Etymology. This species is named D. pseudomorelia because it resembles $D$. morelia in general morphology.

Relationship to other species. Drosophila pseudomorelia belongs to the flavopilosa species group in the subgenus Drosophila. The general shape of the male terminalia, especially the aedeagus, suggests a close relationship to D. morelia.

\section{Discussion}

The D. flavopilosa species group have a restricted larval ecology as the females use flowers in the Solanaceae as their only sites for oviposition. Larvae develop feed in these flowers in South America (Robe et al. 2013). The Central American species may use flowers from other plant families for larval development (Ludwing et al. 2002). Drosophila pseudokorefae was collected using a banana fermented with yeast bait indicating that this 

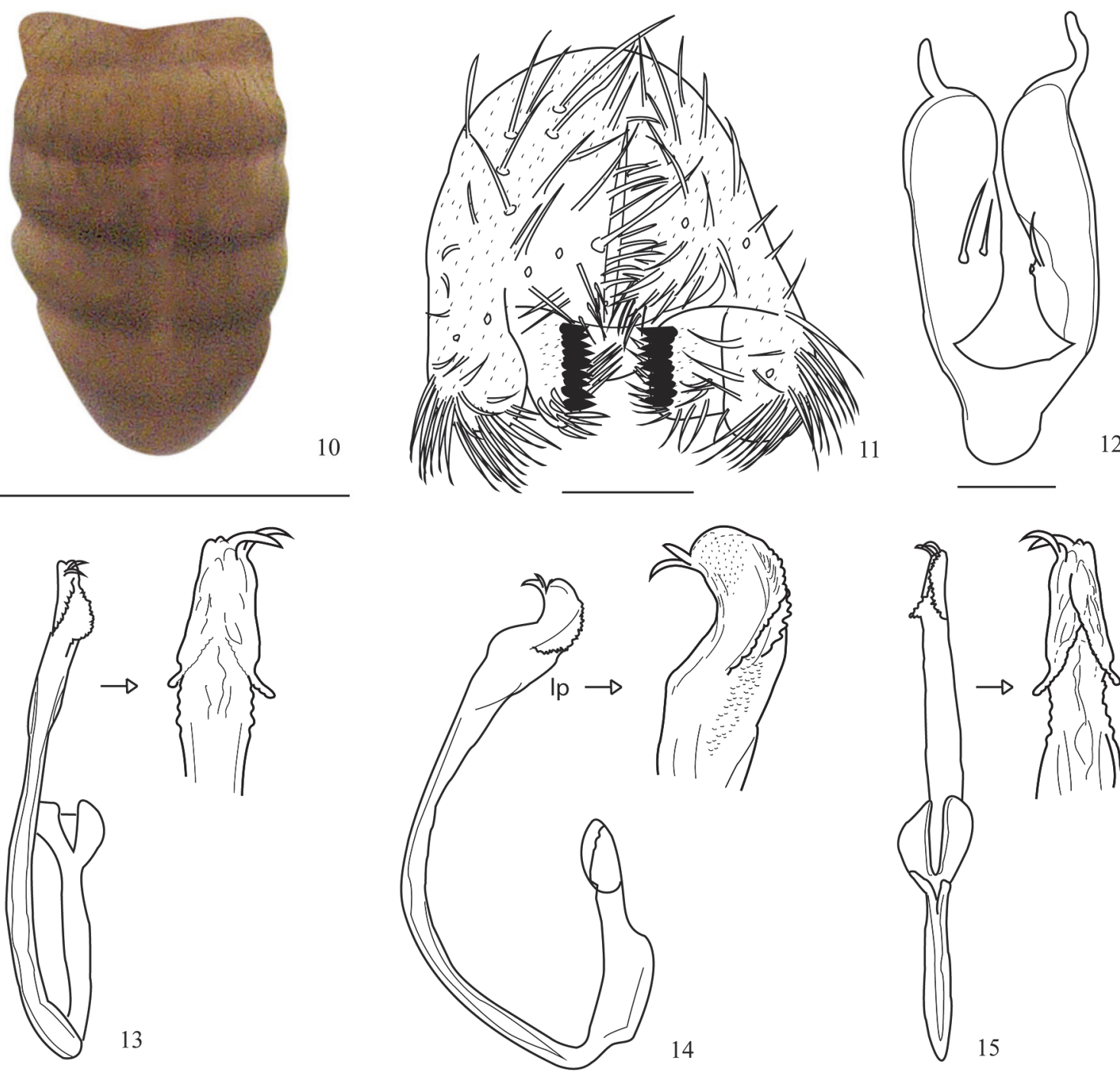

12
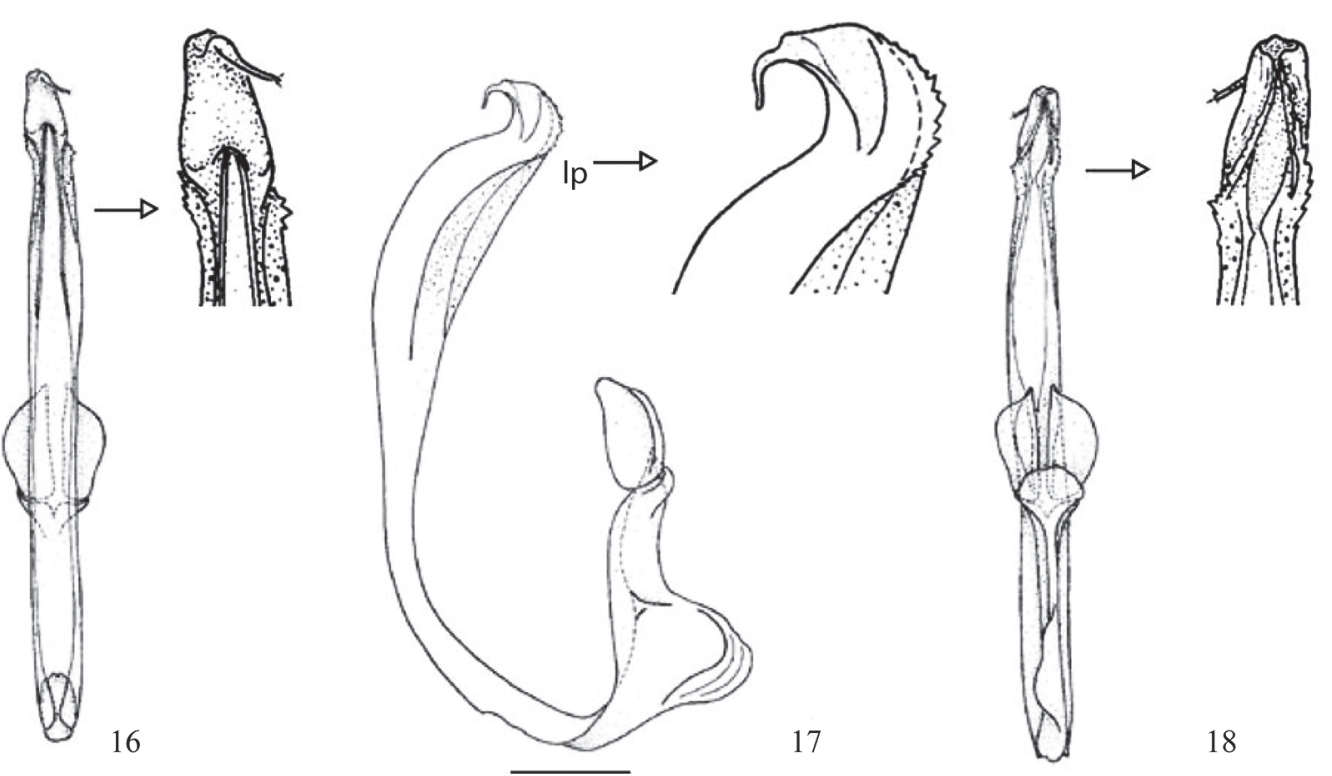

Figures 10 - 18. Drosophila pseudomorelia sp. nov. 10, abdomen (scale bar = 1mm); 11, epandrium, cerci, surstyli and decasternum; 12, hypandrium and gonopods in ventral view; 13-15, aedeagus in dorsal, lateral and ventral view, respectively; $16-18$, aedeagus of $D$. morelia (source: Vilela \& Bächli, 2004) in dorsal, lateral and ventral view, respectively zoom $40 x($ scale bar $=100 \mu \mathrm{m}) \mathrm{Ip}=$ last part. 
species may be attracted to the odors of yeast fermentation and not only solanaceous flowers.

Wheeler et al. (1962) reported that analysis of the male genitalia was the most satisfactory way to identify species morphologically. Using this criterion, D. pseudokorefae is very similar to $D$. korefae but there are significant characteristics that differentiate them. First, D. pseudokorefae has two extra fingershaped projections above the lateral serrated projection of the aedeagal tip and the aedeagal apodeme is wide. Drosophila korefae has two lateral serrated projections without the extra projections and the aedegal apodeme is narrow. Second, D. pseudokorefae does not have rugose spines along the hypandrium and $D$. korefae has many spines. Finally, in D. pseudokorefae the wings are light brown, hyaline posteriorly and the crossvein is slightly infuscate. Drosophila korefae has wings with a shadow in the costal cell and at the tip of the wing (Vela \& Rafael 2004).

There is only one Neotropical species, Drosophila crassa Patterson and Mainland, 1944, whose male terminalia share some superficial features with the species of the $D$. morelia species group, but there are many differences between them (Vilela \& Bächli 2004); therefore, the identification of species in the $D$. morelia species group is less complicated than in the $D$. flavopilosa species group. Drosophila pseudomorelia is similar to D. morelia but $D$. pseudomorelia has a number of different characteristics. First, in D. pseudomorelia the dorsodistal process is thin, curved anteriorly and ends in a double tip (Fig. 14). In Drosophila morelia this process ends in a single tip (Fig. 17). Second, in $D$. pseudomorelia the last part (lp) of the aedeagus (before the tip) is twice as wide as the anterior part. In D. morelia this part (lp) of the aedeagus (before the tip) is three times wider than the anterior part and this widening occupies almost the entire superior half as seen in lateral view. Third, in D. pseudomorelia the hypandrium is without roughness on the posterior side and there are two large horn-shaped projections. The smooth gonopod has two setae. In D. morelia, the hypandrium has short horn-shaped projections and the gonopod is mostly rugose and with one setae. Finally, in $D$. pseudomorelia the wings are without shadowing and $D$. morelia has a diffuse brown patch close to the tip of $\mathrm{R}_{2+3}$, almost reaching backwards to $\mathrm{R}_{4+5}$ and both main crossveins have diffuse shadowing.

\section{Acknowledgements}

We thank Dr. Clifford Keil for his review and valuable comments on early versions of the manuscript and to Dr. Shane F. McEvey for his review of the final version. Lic. Fernanda Salazar assisted with archiving the specimens. Luna Figuero, Diego Céspedes e Isabel Tamayo assisted in the field phase of the project.

\section{Literature cited}

Bächli G., C.R. Vilela, S.A. Escher \& A. Saura. 2004. The Drosophilidae (Diptera) of Fennoscadia and Denmark. Fauna Entomologica Scandinavica 39. Leiden, Boston, Brill. 362p.

Figuero M. \& V. Rafael. 2011. Dos nuevas especies del grupo Drosophila onychophora (Diptera, Drosophilidae) en los bosques de Polylepis de Papallacta, Pichincha, Ecuador. Ingeringia, Série Zoologica 101(4):342-349.

Figuero M., R. León, V. Rafael \& D. Céspedes. 2012. Cuatro nuevas especies del grupo Drosophila onychophora (Diptera, Drosophilidae) en el Parque Arqueológico Rumipamba, Pichincha, Ecuador. Iheringia, Série Zoologica 102(2):212-220.

Frey R. 1919. Mitteilungen uber sudamerikanische Dipteren. Ofversigt af Finska Vetenskaps-Societetens Forhandlingar 60(a) $14: 1-35$.

Hunter A.S. 1988. High altitude flower-breeding Drosophila (Diptera: Drosophilidae). Pan-Pacific Entomologist 64:299-312.

Ludwing A., N. Vidal, E. Loreto \& M. Sepel. 2002. Drosophila incompta development without flowers. Drosophila Information Service 85:40-41.

McEvey S.F. 1990. New species of Scaptomyza from Madagascar and Mauritius with a note on terminology (Diptera: Drosophilidae). Annales de la Société Entomologique de France 26, 51-64.

Patterson, J. \& Mainland, G. 1944. The Drosophilidae of Mexico. The University of Texas Publication. Pp 9-101.

Pipkin S., R. Rodríguez \& J. León. 1966. Plant host specificity among flower-feeding Neotropical Drosophila (Diptera: Drosophilidae). American Naturalist 100:135-156.

Robe L., F. De Rè, A. Ludwig \& E. Loreto. 2013. The Drosophila flavopilosa species group (Diptera, Drosophilidae): An array of exciting questions. Fly 7(2):59-69.

Santos R. \& C. Vilela. 2005. Breeding sites of Neotropical Drosophilidae (Diptera): IV. Living and fallen flowers of Sessea brasiliensis and Cestrum spp. (Solanaceae). Revista Brasileira de Entomología 49(4):544-551.

Sturtevant A.H. 1921. Genetic studies on Drosophila simulans. II. Genetics 6:43-64.

Vela D. \& V. Rafael. 2004. Dos nuevas especies del grupo flavopilosa, género Drosophila (Diptera, Drosophilidae) en el Bosque Pasochoa. Revista Ecuatoriana de Medicina y Ciencias Biológicas 26:33-39.

Vela D. \& V. Rafael. 2005. Catorce nuevas especies del género Drosophila (Diptera, Drosophilidae) en el bosque húmedo montano del Volcán Pasochoa, Pichincha, Ecuador. Revista Ecuatoriana de Medicina y Ciencias Biológicas XXVII (1 y 2):27-41.

Vilela C. \& G. Bächli. 2004. Revisions of the Drosophila macroptera and D. rubrifrons species groups, with description of a new Neotropical group (Diptera, Drosophilidae). Mitteilungen der Schwezerischen Entomologischen Gesellschaft. Bulletin de la Société Entomologique Suisse 77: 1-68.

Vilela C. \& G. Bächli. 1990. Taxonomic studies on Neotropical species of seven genera of Drosophilidae (Diptera). Bulletin de la Societé Entomologique Suisse 63:1-332.

Wheeler M., H. Takada \& D. Brncic. 1962. The flavopilosa species group of Drosophila. The University of Texas Publication. Pp 395-413. 